\title{
INFLUENCE OF INKJET PRINT PARAMETERS ON THERMAL RESISTANCE OF PRINTED KNITWEARS
}

\author{
Mladen Stančić (D), Branka Ružičić (D), Đorđe Vujčić (D), Dragana Grujić (D), \\ Miroslav Dragić (D), Bojan Janković \\ University of Banja Luka, Faculty of Technology, Banja Luka, Bosnia and Herzegovina
}

\begin{abstract}
Textile materials are increasingly being subjected to the process of printing. The printing process with its parameters significantly affects the properties of textile materials and clothes made from these materials. This paper examines the effect of the parameters of inkjet printing on thermal resistance characteristics of printed textile materials. As the essential print parameters were selected tone value and a different number of passes. In this research were used knitted fabric materials of 100\% cotton fibers and $100 \%$ polyester fibers. Results of the research demonstrated that, in addition to material composition, the inkjet printing process with its parameters have a significant influence on the thermal resistance of printed textile materials. The values of the thermal resistance of the printed samples show that the increase in the number of applications of ink in the printing results in a rise in the value on cotton knitwear, and decrease in thermal resistance value on polyester knitwear.
\end{abstract}

Keywords: Inkjet textile printing, Thermal resistance

\section{INTRODUCTION}

For the past decade, many innovations and the launching of new, improved machines brought Inkjet printing technologies a worldwide annual growth rate of $11 \%$ (Tyler, 2011). This has been achieved by the parallel development of inks, printing technologies and new application areas. Inkjet printing technology provides possibilities for new design styles and workflows, short production runs, sustainable printing environments, quick response time, and customization. One of the most significant contributions of this technology is the concept of the neo-cottage industry (Ujiie, 2005). Mostly used materials for clothing are cotton and polyester, or those two combined. From the whole amount of printed textile materials $35 \%$ is print on cotton, $25 \%$ on polyester and 16\% on the mixture substrate (Stančić, 2016; Momin, 2008; Siemensmeyer et al, 1999). Digital printing efficiency, as flexible way of ink transfer on substrate in the form of a desirable design, is primarily reflected in respect of costs and time needed for production of smaller circulations (Novaković et al, 2010). Besides that, digital printing technique enables faster response to market demands and mass individualization. More important, for clothes, is to meet the ergonomic and physiological requirements (Mecheels, 1992). Comfort is a basic and universal need of a human being and represents one of the most important aspects of clothing. When wearing clothes, the heat and humidity produced by the body stop as layers of air before passing into the environment, resulting in a characteristic microclimate between skin and clothing and is defined as a feeling of comfort (Yoo et al, 2000; Grujić et al, 2010). One of the most important thermal characteristics of clothing is, of course, thermal resistance; which represents the ability of a material to resist heat transfer. The thermal resistance of garments, made of a number of textile materials, mostly depends on the thickness and porosity of individual layers (Matusiak, 2010). Thus, increasing the thickness of the material leads to an increase in the value of thermal resistance (Oğlakcioğlu and Marmarali, 2007). To a lesser extent, the thermal resistance of textile materials is also determined by the thermal conductivity of the fibers of the material (Haghi, 2004). It is expected that there is an inverse relationship between thermal resistance and thermal conductivity. However, the results of various tests have shown that there are certain cases in which the increase in thermal conductivity leads to an increase in the thermal resistance of garments. This can be explained by the structural characteristics and thickness of the material. Namely, in the case that the volume increase of the material thickness is greater than the volume increase of the thermal conductivity of the material, there will be an increase in the value of thermal resistance (Chidambaram et al, 2012; Oğlakcioğlu and Marmarali, 2007). In the printing process, a layer of ink is transferred to the clothes, and part of the printing ink covers the surface clothing, while the other part fills the pores between the fibers. In this way the paint represents a new layer material, i.e. an additional barrier in heat transfer from the body surface to the environment. This paper will show the influence of this new layer of material obtained by the printing process on the thermal resistance of clothing. The influence of the number of ink applications and the tone value, as well as the influence of material type, are making a 
difference on the thermal resistance of printed textile materials. The thermal resistance of textile materials is very important characteristic to the degree of comfort that the user perceives from clothing. The thermal resistance of textile materials depends on the type of fiber. Then a layer of printing ink is applied to and in the textile material by the printing process. Printing ink covers the surface of the fibers, making a significant influence on the thermal resistance of textile material (Kašiković et al, 2019).

\section{METHODS AND MATERIALS}

Research of the effect of tone value and a different number of ink applications on thermal resistance was performed on two types of textile knitwear, of approximately the same surface mass and surface structures but different material composition. Material characterization was done according to following parameters: material composition (International Organisation for Standardization 1833, 2006), fabric weight (International Organisation for Standardization 3801, 1977) and thread count (International Organisation for Standardization 7211-2, 1984). Characteristics of the materials are presented in Table 1.

Table 1: Basic characteristics of materials used in research

\begin{tabular}{|c|c|c|c|c|c|c|}
\hline \multirow{2}{*}{$\begin{array}{l}\text { Code of } \\
\text { fabrics }\end{array}$} & \multirow{2}{*}{$\begin{array}{c}\text { Type of } \\
\text { materials }\end{array}$} & \multirow{2}{*}{$\begin{array}{l}\text { Type of } \\
\text { weaves }\end{array}$} & \multirow{2}{*}{$\begin{array}{c}\text { Raw material } \\
\text { composition (\%) }\end{array}$} & \multirow{2}{*}{$\begin{array}{l}\text { Mass per unit } \\
\text { weight }\left(\mathrm{g} / \mathrm{m}^{2}\right)\end{array}$} & \multicolumn{2}{|c|}{ Density $\left(\mathrm{cm}^{-1}\right)$} \\
\hline & & & & & Warp & Weft \\
\hline $\mathrm{CO}$ & Knitwear & Single & Cotton $100 \%$ & 111.89 & 17 & 17 \\
\hline PES & Knitwear & Single & Polyester 100 \% & 114.12 & 12 & 20 \\
\hline Method & & & ISO 1833 & ISO 3801 & ISO & $1-2$ \\
\hline
\end{tabular}

For this study it was created a special test image using Adobe Illustrator CS5 software. Test image contained $200 \times 200 \mathrm{~mm}$ patches, with $10 \%, 50 \%$ and $100 \%$ tone values of cyan process colour. Samples were printed by ink-jet printing system Polyprint TexJet. Samples were printed in one, three and five passes, resolution $720 \times 720$ dpi. It was printed with water-based inks (DuPont Artisti Pigment Ink - P5100 Cyan). Because of a need for a low viscosity, inks contain demineralised water (51\%), the appropriate pigment (1-5\%), poly(oxyethylene) (14\%), ethane-1.2-diol (12\%), 1- methyl-2-pyrrolidone (15\%), poly(1hydroxyethylene) (3\%), tris(2-hydroxyethyl)amine (1\%), biocide $(0.1 \%)$ and buffer $(0.3 \%)$. Ink fixation was performed at a temperature of $130{ }^{\circ} \mathrm{C}$ for 120 seconds. Thermal resistance, i.e. thermal insulation, is greatest when a person is at rest, because then the air under clothes is also at rest. Examination of thermal resistance of knitwear is performed with KES-F7 (Thermo Labo II) measuring device with a larger measuring body BT, which is located in the wind tunnel and which is heated to a temperature of $35^{\circ} \mathrm{C}$. At the same time, the air in the wind tunnel was constantly moving at a speed of $1 \mathrm{~ms}^{-1}$, at a temperature of $20{ }^{\circ} \mathrm{C} \pm 2{ }^{\circ} \mathrm{C}$. Constant air movement is achieved by turning on the fan. Heat loss or heat flow can be determined by the following methods: dry contact method, dry non-contact method, wet contact method, wet non-contact method. The dry non-contact method was used to analyse the thermal resistance of textile materials according to the expression (Kato Tech Co. Ltd., 1998):

$R_{c}=\frac{\left(T_{s}-T_{a}\right) \cdot A}{H_{c t}}$

where:

- $\mathrm{Rc}$ - heat resistance of textiles [ $\left.\mathrm{m}^{2} \mathrm{~K} / \mathrm{W}\right]$,

- Hct - dry heat flow, which goes through the material [W],

- A - Area of the BT measuring body $\left[\mathrm{m}^{2}\right]$,

- Ts - temperature of the BT measuring body (skin temperature) $\left[{ }^{\circ} \mathrm{C}\right]$,

- $\mathrm{Ta}$ - air temperature $\left[{ }^{\circ} \mathrm{C}\right]$. 


\section{RESULTS AND DISCUSSION}

The results of the research on the influence of printing parameters, i.e. tone values and number of ink applications, and properties of materials (raw material composition and surface structure) on a change of thermal resistance of printed textile materials, are presented below.

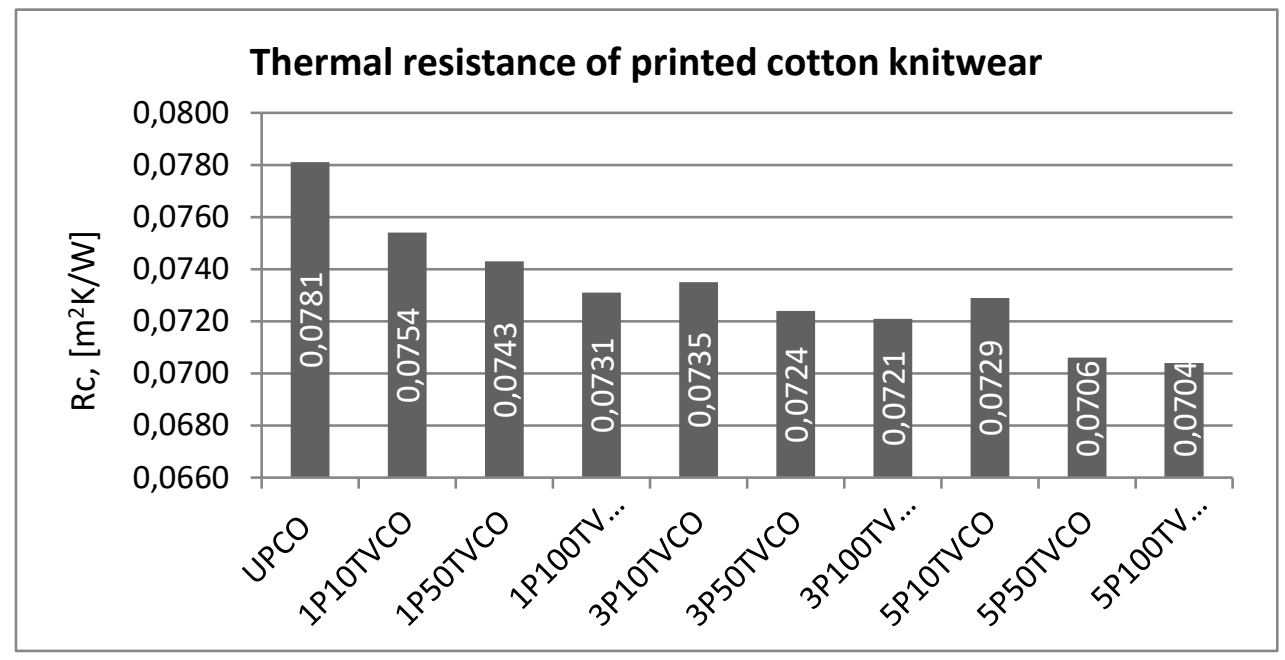

Figure 1: Thermal resistance of cotton knitwear subjected to the printing process (Note: UP - Unprinted, 1P, 3P and 5P mark indicates the print with 1, 3 and 5 passes, 10TV, 50TV and 100TV denote a print with 10\%, 50\% and 100\% of tonal values, CO stands for cotton)

The measured values of thermal resistance of printed cotton knitwear materials (CO) are shown in Figure 1. They are noticeably lower than the given values of the unprinted sample. It can be also noticed that the thermal resistance of printed cotton knitwear decreases with increasing of ink coverage. At the same time, with the increase in the number of ink applications, there is also a decrease in the value of thermal resistance. By analyzing the values of thermal resistance of printed cotton knitwear, it can be noticed that by combining the tone value and the number of ink applications, it is possible to achieve similar values of thermal resistance. The obtained results showed that approximately equal values of thermal resistance were obtained by printing samples with 10\% TV with five coats of ink and 100\% TV with one coat of ink.

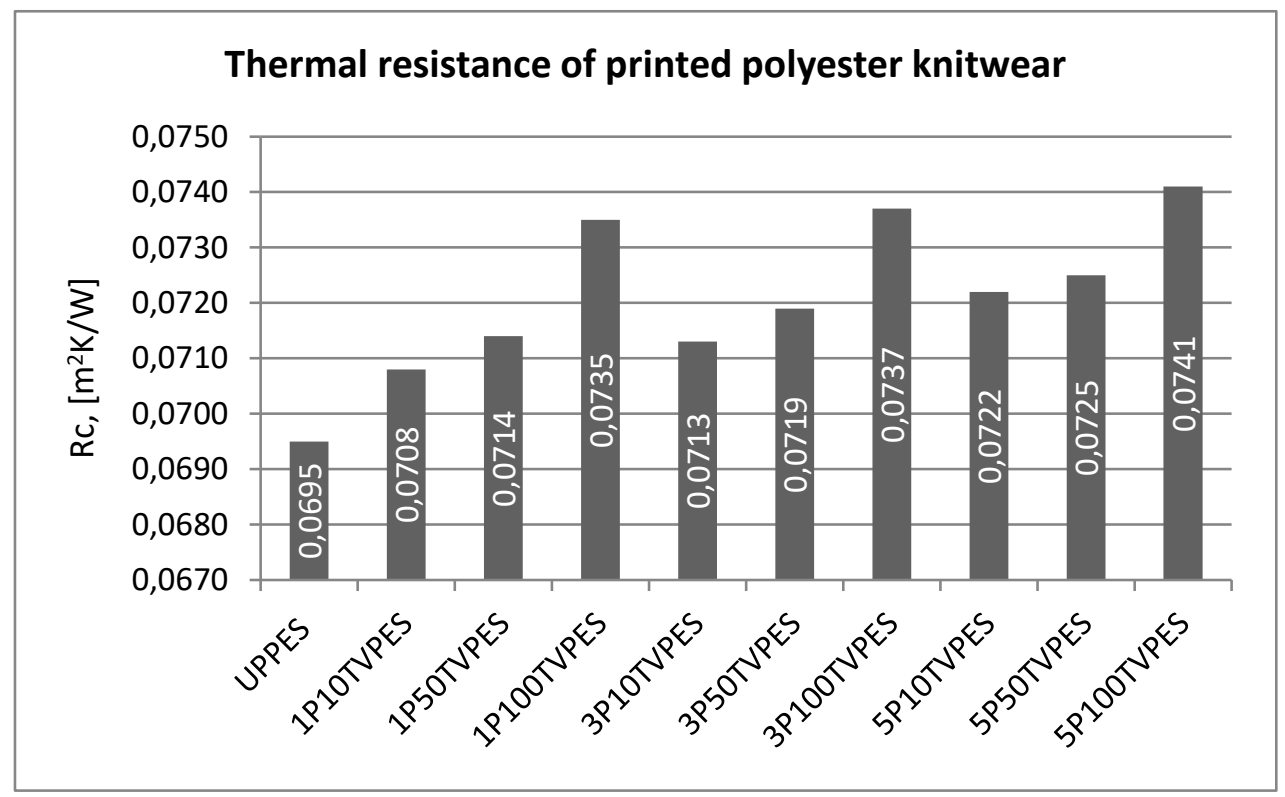

Figure 2: Thermal resistance of polyester knitwear subjected to the printing process (Note: UP - Unprinted, 1P, 3P and 5P mark indicates the print with 1, 3 and 5 passes, 10TV, 50TV and 100TV denote a print with 10\%, 50\% and 100\% of tonal values, PES stands for polyester) 
The results of thermal resistance analysis of printed polyester knitwear (PES) are shown in Figure 2. It can be noticed that increasing of the tone value leads to an increase in the value of thermal resistance. At the same time, the obtained measurement results indicate that as the number of ink applications increases, the values of thermal resistance increase, regardless of whether the samples were printed in one, with three or five ink applications. It is also noticed that the polyester knitwear obtained higher values of thermal resistance in the printing process in relation to the values that occur with unprinted material. Further analysis of the obtained results shows that approximately equal values were obtained in the case of printing samples with $10 \%$ TV with three print passes and $50 \%$ TV with one print pass, and in the case of printing 10\% TV with five print passes and 50\% TV with three print passes.

In order to determine dependence of thermal resistance of printed cotton and polyester knitwear, when printing with different tone value (TV) and different number of ink applications (NP), mathematical dependence models were created using multiple regression analysis. In creating model, as independent variable value were used printing process parameter values, i.e. values of ink layers applications and tone values. At the same time, as the dependent variable values were used experimentally obtained values of measuring thermal resistance of tested knitwear. Results are presented in Table 2 and Table 3.

Table 2: Values of multiple linear regression coefficients for the obtained mathematical models of the dependence of thermal resistance on tone values and the number of print passes for the tested cotton materials (Note: TV - tonal value, NP-number of passes)

\begin{tabular}{|c|c|c|c|c|c|c|c|c|c|c|}
\hline \multicolumn{11}{|c|}{$R_{c}=0,076-0,000022 \cdot T V-0,001 \cdot N P$} \\
\hline $\begin{array}{l}\text { Multiple } \\
\text { regression }\end{array}$ & Std. error of & \multicolumn{3}{|c|}{$b_{\circ}=0,076$} & \multicolumn{3}{|c|}{$b_{1}=-0,000022$} & \multicolumn{3}{|c|}{$b_{2}=-0,001$} \\
\hline$R^{2}$ & $\mathrm{~s}$ & std. error & $\mathrm{t}$ & $P$ & std. error & $\mathrm{t}$ & $P$ & std. error & $\mathrm{t}$ & $P$ \\
\hline 0,930 & 0,0004919 & 0,000417 & 182,581 & $1,8213 \cdot 10-12$ & 0,000004 & $-5,049$ & 0,002 & 0,0001 & $-7,386$ & 0,000316 \\
\hline
\end{tabular}

Table 3: Values of multiple linear regression coefficients for the obtained mathematical models of the dependence of thermal resistance on tone values and the number of print passes for the tested polyester materials (Note: TV - tonal value, NP-number of passes)

\begin{tabular}{|c|c|c|c|c|c|c|c|c|c|c|}
\hline \multicolumn{11}{|c|}{$R_{c}=0,070+0,000026 \cdot T V+0,000258 \cdot N P$} \\
\hline $\begin{array}{l}\text { Multiple } \\
\text { regression }\end{array}$ & Std. error of & \multicolumn{3}{|c|}{$b_{0}=0,070$} & \multicolumn{3}{|c|}{$b_{1}=0,000026$} & \multicolumn{3}{|c|}{$b_{2}=0,000258$} \\
\hline $\mathrm{R}^{2}$ & $\mathrm{~s}$ & std. error & $t$ & $P$ & std. error & $t$ & $P$ & std. error & $t$ & $P$ \\
\hline 0,929 & 0,0003589 & 0,000304 & 230,631 & $4,4840 \cdot 10-13$ & 0,000003 & 8,115 & 0,000188 & 0,000073 & 3,526 & 0,012 \\
\hline
\end{tabular}

The results show statistically reliable dependences of thermal resistance on tone values and the number of passes when printing for the test of cotton and polyester knitwear.

\section{CONCLUSION}

Textile materials are increasingly being subjected to the process of printing. This paper examines the effect of the parameters of digital printing on thermo-physiological characteristics of printed textile materials. For this purpose, the influence of the tone value and different number of ink applications on the thermal resistance. In the analysis of cotton knitwear it was noted that increase of the tone values as well as increase of number of ink applications leads to increase of the thermal resistance. In printing the polyester knitwear initial increase of tone value results in reduction of thermal resistance. This confirms that the change in the tone value or the number of ink applications, as the parameters of digital printing, can affect change in thermal resistance.

The values of thermal resistance highly depend on the surface structure of the material. For all tested materials, it is possible to create mathematical models of the dependence of thermal resistance on the number of ink applications and tone value.

Summarizing the results, it can be concluded that the print parameters have an important effect on thermal resistance, as one of the parameters of textile materials thermal comfort. In order to further 
knowledge it is planned to test how other process colours affect the studied parameters. Also, research is needed to expand to other physiological parameters of thermal comfort, such as thermal conductivity, warm and cold feeling, resistance to the flow of water vapour and others. In addition to the knitwear tests, listed research is needed to carry out on fabrics too.

\section{REFERENCES}

[1] Chidambaram, P., Govindan, R., Venkatraman, K. C.: „Study of Thermal Comfort Properties of Cotton/Regenerated Bamboo Knitted Fabrics", African Journal of Basic and Applied Sciences 4 (2), 60-66, 2012. doi:10.5829/idosi.ajbas.2012.4.2.1032.

[2] Grujić, D., Geršak, J., Ristić, M.: „Uticaj fizikalnih i sorpcijskih svojstava tkanina na količinu upijenog znoja u odjeći“ Tekstil, 59 (3), 68-79, 2010.

[3] Haghi, A.K.: „Moisture Permeation of Clothing, A Factor Governing Thermal Equilibrium and Comfort", Journal of Thermal Analysis and Calorimetry 76 (3), 1035-1055, 2004. doi: 10.1023/B:JTAN.0000032288.16502.d2.

[4] International Organisation for Standardization, ISO 3801:1977 Textiles - Woven fabrics -Determination of mass per unit length and mass per unit area, Geneva, International Organisation for Standardization, 1977.

[5] International Organisation for Standardization, ISO 7211-2:1984 Textiles - Woven fabrics -Construction -- Methods of analysis -- Part 2: Determination of number of threads per unit length, Geneva, International Organisation for Standardization, 1984.

[6] International Organisation for Standardization, ISO 1833-1:2006 Textiles - Quantitative chemical analysis -- Part 1: General principles of testing, Geneva, International Organisation for Standardization, 2006.

[7] Kašiković, N., Novaković, D., Stančić, M.: „Procesni parametri štampe tekstilnih materijala“, monografija, (Fakultet tehničkih nauka u Novom Sadu, Novi Sad, 2019), pages 282-292.

[8] Kato Tech Co. Ltd.: "Operating Instruction KES-F7: Manual for KES-F7 Thermo Labo II (Precise and Prompt Thermal Prosperity Measurement Instrument)“, Kyoto Tech Co. Ltd, 1998.

[9] Matusiak, M.: „Thermal Comfort Index as a Method of Assessing the Thermal Comfort of Textile Materials", Fibres and Textiles in Eastern Europe 18 (2), 45-50, 2010. URL: http://www.fibtex.lodz.pl/2010/2/45.pdf (last request: 2020-21-10).

[10] Mecheels, J.: „Anforderungsprofile für Funktionsgerechte Bekleidung“, DWI -Schriftenreihe des Deutschen Wollforschungsinstitutes an der TH Aachen, Aachener Teksiltagung, 109, 263-268, 1992.

[11] Momin, N. H.: "Chitosan and Improved Pigment Ink Jet Printing on Textiles", PhD thesis, School of Fashion and Textiles, RMIT University, Melbourne, 2008.

[12] Novaković, D., Kašiković, N., Zeljković, Ž., Agić, D. i Gojo, M.: „Thermographic Analysis of Thermal Effects on the Change of Colour Differences on the Digitally Printed Textile Materials", Tekstil 59 (7), 297-306, 2010. URL:

https://www.researchgate.net/publication/215601315_Thermographic_analysis_of_thermal_effect s_on_the_change_of_colour_differences_on_the_digitally_printed_textile_materials/link/09e41506 9c4d00960a000000/download (last request: 2020-21-10).

[13] Oğlakcioğlu, N., Marmarali, A.: "Thermal Comfort Properties of Some Knitted Structures", Fibres and Textiles in Eastern Europe 15 (5-6), 94-96, 2007. URL: http://www.fibtex.lodz.pl/64_26_94.pdf (last request: 2020-21-10).

[14] Siemensmeyer, K., Seigel, B., Ervine, S., Bullock, J.: "Solutions for Digital Textile Printing", Proceedings of IS\&Ts NIP 15: International Conference on Digital Printing technology 1999, (IS\&Ts NIP 15: Orlando, Florida, 1999), pages 280-283.

[15] [15] Stančić, M.: "Model of thermal properties of printed garment", PhD thesis, Faculty of Technical Sciences, Novi Sad, 2016.

[16] Tyler, D. J., „Digital printing technology for textiles and apparel“, (Editor(s): Jinlian Hu, In “Woodhead Publishing Series in Textiles, Computer Technology for Textiles and Apparel“, Woodhead Publishing, 2011), pages 259-282.

[17] Ujiie, H., „Innovative Product Development in Digital Fabric Printing", 2005, URL: http://www.hitoshiujiie.com/Documents/libraryResearch/WebCons05.pdf (last request: 2020-2110). 
[18] Yoo, H. S., Hu, Y. S., Kim, E. A.: „Effect of Heat and Moisture Transport in Fabrics and Garments Determined with a Vertical Plate Sweating Skin Model“, Textile Research Journal 70 (6), 542-549, 2000. doi: 10.1177/004051750007000612.

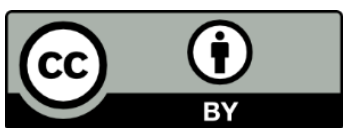

(C) 2020 Authors. Published by the University of Novi Sad, Faculty of Technical Sciences, Department of Graphic Engineering and Design. This article is an open access article distributed under the terms and conditions of the Creative Commons Attribution license 3.0 Serbia

(http://creativecommons.org/licenses/by/3.0/rs/). 